\title{
Influence of castration and postnatal energy restriction on the contractile and metabolic characteristics of bovine muscle
}

\author{
B Picard, J Robelin, Y Geay \\ INRA-Theix, laboratoire croissance et métabolismes des herbivores, \\ 63122 Saint-Genès-Champanelle. France
}

(Received 25 July 1994; accepted 5 January 1995)

\begin{abstract}
Summary - Twenty-four Montbeliard calves were raised with milk replacer to achieve a high or low rate of gain, 1167 and $658 \mathrm{~g} / \mathrm{d}$, respectively. At $146 \mathrm{~kg}$, the animals were weaned and 6 calves from each group were castrated. Thereafter, and until slaughter, animals of the same weight received the same diet in both groups. Biopsy samples of Semitendinosus (ST) muscle were taken in all animals at $140 \mathrm{~kg}, 305 \mathrm{~kg}$, and at slaughter, $541 \mathrm{~kg}$. The biochemical, contractile and metabolic characteristics of the ST samples were analyzed. The results showed that castration at the age of 4 months had a significant effect only on muscle characteristics measured at slaughter, 13 months after castration. The muscles of the steers contained smaller fibers, fewer type IIA fibers and more type IIB fibers than those of the bulls. In contrast, feed restriction before weaning resulted in changes to fiber characteristics after weaning at $305 \mathrm{~kg}$. Restricted animals had smaller muscle fibers, a lower percentage of type I fibers and a higher percentage of type IIB fibers than animals fed ad libitum. These changes were no longer observed at slaughter.
\end{abstract}

muscle / fiber type / castration / feed restriction

Résumé - Influence de la castration et de la restriction énergétique postnatale sur les caractéristiques contractiles et métaboliques des muscles de bovins. Vingt-quatre veaux Montbéliards âgés d'environ 3 sem ont été répartis en 2 groupes. Le premier a reçu une ration permettant un gain moyen quotidien (GMQ) de $1167 \mathrm{~g} / \mathrm{j}$, le second a été limité à un GMQ de $658 \mathrm{~g} / \mathrm{j}$ jusqu'à la fin du sevrage, à l'âge de 4 mois en moyenne. Ensuite, jusqu'à l'abattage, les 2 groupes ont reçu, à même poids, le même régime. La moitié des animaux de chaque groupe a été castrée à 4 mois. Des échantillons du muscle Semitendinosus (ST) ont été prélevés par biopsie sur l'ensemble des animaux, à 2 stades correspondant respectivement à un poids moyen de $140 \mathrm{~kg}$ (à la fin du sevrage), $305 \mathrm{~kg}$ (9 mois environ) et à l'abattage à un poids moyen de $541 \mathrm{~kg}$ (à 17 mois en moyenne). Sur ces échantillons les caractéristiques biochimiques, contractiles et métaboliques du muscle ST ont été analysées. La castration à 4 mois n'a pas d'effet significatif sur les caractéristiques musculaires mesurées à 9 mois. En revanche, à l'abattage, 13 mois après castration, les animaux castrés par rapport aux animaux entiers, renferment moins de fibres de type $\| A$ et plus de fibres de type $\| B$; enfin, ils présentent des fibres mus- 
culaires de plus petite section. La restriction alimentaire avant le sevrage entraine des modifications des caractéristiques des fibres qui sont encore mesurables 5 mois après le sevrage : les animaux restreints ont des fibres de plus petite section, un pourcentage de fibres IIA plus faible, et un pourcentage de fibres IIB supérieur à celui des animaux alimentés ad libitum. Ces modifications n'apparaissent plus à l'abattage, 8 mois plus tard. Une restriction énergétique appliquée avant le sevrage a donc des conséquences réversibles sur les caractéristiques musculaires.

muscle / type de fibre / castration / restriction énergétique / alimentation

\section{INTRODUCTION}

The commercial value of cattle depends on the muscle mass of the carcass and its adipose deposit content. The palatability of meat is partly governed by the contractile and metabolic characteristics of the muscles. Diet and castration can modify the growth rate of the different tissues. Steroid hormones affect the development of muscles and their biological characteristics and hence the quality of the meat. The meat of cows is more tender than that of steers and bulls (Field, 1971; Seideman et al, 1982). However, these effects depend on the muscle: the sensitivity of the neck, shoulder, cheek and thigh muscles to androgens decreases in that order (Butterfield, 1988). Certain muscles have sexual dimorphism, in particular the Splenius in cattle (Young and Bass, 1984), the Temporalis in guinea pigs (Bass et al, 1971; Lyons et al, 1986), the larynx in Xenopus laevis (Sassoon et al, 1987; Kelley et al, 1989) and the Levator ani in rats (D'Albis et al, 1991). Late castration is often performed in cattle to achieve rapid growth in the young animal and greater meat tenderness at slaughter.

Feed intake is another factor in cattle rearing that can modify growth rate, carcass composition and muscle characteristics. The effects on muscle characteristics vary depending on whether feed restriction is implemented before or after weaning $(\mathrm{Hal}-$ tia et al, 1978; Goldspink and Ward, 1979; Beverly et al, 1991; Yambayamba and Price, 1991). There is little available evidence on postnatal energy restriction in cattle. In rats, postnatal restriction had irreversible effects (Bedi et al, 1982; Beverly et al, 1991). In contrast, Nordly et al (1987) showed that a restricted energy diet in gestating ewes had no effect on the muscle fiber characteristics of lambs observed at slaughter.

The aim of this study, therefore, was to determine the influence of castration and energy restriction in the early postnatal period on the contractile and metabolic characteristics of bovine muscle during the growth phase and at slaughter, which was performed, on average, at 17 months of age.

\section{MATERIALS AND METHODS}

\section{Animal management and muscle sampling}

Twenty-four newborn Montbeliard calves were allocated, by age, weight and birth weight to 2 groups (I and II). At an average age of 4 months, the animals of the 2 groups were weaned when they attained $146 \mathrm{~kg}$. Six calves from each group were castrated.

During the milk feeding period, group I received ad libitum a diet of reconstituted milk to achieve a high rate of gain $(1167 \mathrm{~g} / \mathrm{d})$, whereas the animals of group $\mid 1$ received a restricted diet of reconstituted milk to achieve a low rate of gain $(658 \mathrm{~g} / \mathrm{d})$. In the postweaning period, animals of the same weight were fed the same diet of $70 \%$ corn silage and $30 \%$ concentrate, calculated for a predetermined body weight gain of $1100 \mathrm{~g} / \mathrm{d}$. 
During these 2 periods, all of the animals were weighed weekly.

The circulating testosterone concentration was measured by radioimmunoassay at 4 months, just before castration, after castration and at 9 months.

Biopsy samples of Semitendinosus (ST) muscle were taken in animals of both groups at 3 stages (fig 1):

Stage 1: during the weaning period at the end of feed restriction (mean weight $146 \mathrm{~kg}$ ),

Stage 2: 5 months after castration and the end of restriction (mean weight $305 \mathrm{~kg}$ ),

Stage 3: at slaughter (mean weight $541 \mathrm{~kg}$ )

The effect of castration was studied on samples taken during stages 2 and 3 and that of diet on samples from stages 1,2 and 3 . The samples were frozen in isopentane and then in liquid nitrogen and stored at $-80^{\circ} \mathrm{C}$.

\section{Muscle analysis}

\section{Determination of protein/DNA ratio}

Total muscle protein content, expressed in $\mathrm{mg} / \mathrm{g}$ of muscle, was determined according to the method of Lowry et a/ (1951) with a preparation of $1 \mathrm{mg} / \mathrm{ml}$ of bovine albumin serum as standard. The DNA content, expressed in $\mu \mathrm{g} / \mathrm{g}$ of muscle, of the samples taken at slaughter was measured by the method of Labarca and Paigen (1980).
The protein/DNA ratio was expressed in $\mathrm{mg}$ of protein per mg of DNA.

\section{Determination of contractile type of muscle fibers}

\section{Histological, immunohistochemical and histochemical studies}

Serial sections $10 \mu \mathrm{m}$ thick were cut perpendicular to the muscle fibers with a cryotome at $-25^{\circ} \mathrm{C}$. Three types of staining were performed on the sections to determine the size of the fibers, their contractile activity and their metabolic activity.

The muscle fibers were treated with azorubine, which stains all fibers irrespective of contractile or metabolic type. It shows the general histological architecture of the muscle and thereby allows determination of the number and diameter of the fibers. Slow (I) and fast (II) contractile types were determined by immunohistochemistry according to the immunofluorescence technique described by Pons et al (1986), who used monoclonal antibodies specific to myosin heavy chains (MHC). Their production, purification and characterization have been described by Léger et al (1985). Their reactivity in cattle has been tested by Robelin et al (1993). Type IIA (oxidoglycolytic) fibers were distinguished from type IIB (glycolytic) by succinate dehydrogenase (SDH) activity according to the method of Pearse (1968). This enzyme, which is present in the cell wall of mitochondria, is characteristic of an oxidative metabolism. Fibers of this metabolic type (I, IIA) stained dark blue in the presence of nitro-

Fig 1. Experimental design. Stage 1 corresponds to the end of the period of energy restriction when biopsy samples were taken in the 2 groups of 6 animals at a mean age of 4 months and a mean weight of $146 \mathrm{~kg}$. Stage 2 corresponds to the second biopsy when animals had a mean age of 9 months and a mean weight of $305 \mathrm{~kg}$. Stage 3 corresponds to slaughter, performed at a mean age of 17 months for a mean weight of $541 \mathrm{~kg}$.

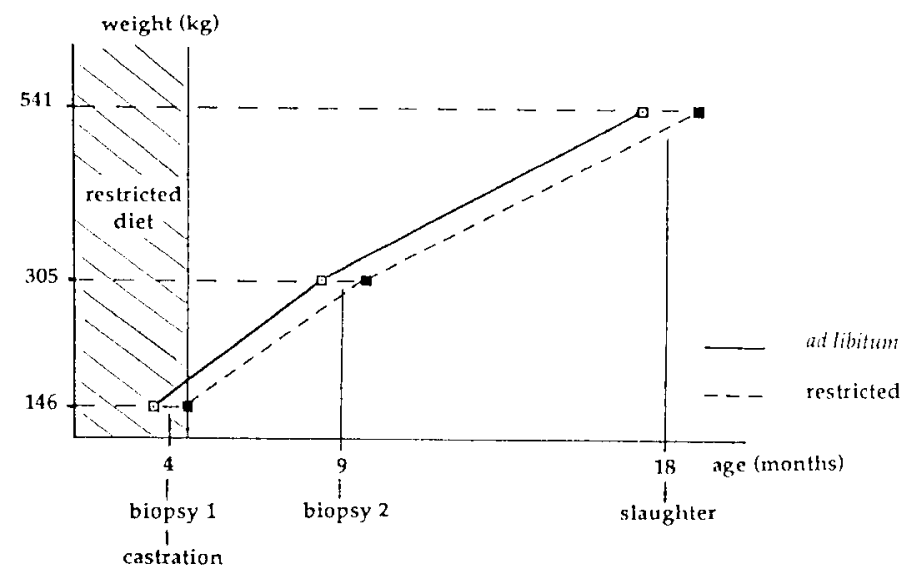


bleutetrazolium, which is reduced by the action of the enzyme, whereas glycolytic fibers (IIB) stained pale blue. A fourth type of fiber, IIC, was evidenced. The cells were recognized by both antiMHC1 (slow) and anti-MHC2 (fast) antibodies and had an oxidoglycolytic metabolism.

The proportion of each type of fiber and their average area were determined in 2 different sites on each serial section. Between 100 and 200 fibers were analyzed by an image-analysis computer program (Visilog).

\section{ELISA: enzyme-linked immunosorbent assay}

This technique was used to quantify the proportion of slow isoform MHC1. It was based on the method of Winkelman et al (1983) modified by Picard et al (1994).

\section{Determination of muscle metabolic type}

The metabolic type of the muscles studied was determined by measuring the enzyme activities of isocitrate dehydrogenase (ICDH) according to the method of Briand et al (1981) and of lactate dehydrogenase (LDH) by the method of Ansay (1974). ICDH activity was measured only on the samples taken at slaughter since the biopsy specimens were not large enough to permit the performance of all the assays.

\section{Analysis of results}

The results were subjected to analysis of variance with the GLM module of the SAS package (1985), to study the effect of castration and diet.

\section{RESULTS}

\section{Effects of castration}

At slaughter, the castrated animals had a lower muscle weight and a greater overall amount of adipose deposit content than the bulls (fig 2).
There was no significant difference in muscle characteristics between the bulls and the animals castrated at stage 2, 5 months after castration. In contrast, 13 months after castration, the steers had a lower oxidative metabolism and a smaller proportion of MHC1 than the bulls (fig 3 ). Their muscles contained significantly lower proportions of type IIA fibers and a significantly higher percentage of type IIB (fig 4), and the surface of all their muscle fibers was smaller (fig 5 ).

\section{Effects of energy restriction}

There was no significant difference at slaughter between restricted animals and those fed ad libitum in total adipose tissue content, muscle and skeleton weight (fig 6). However, significant differences were found at stage 2, 5 months after diet restriction, but at slaughter were no longer observed.
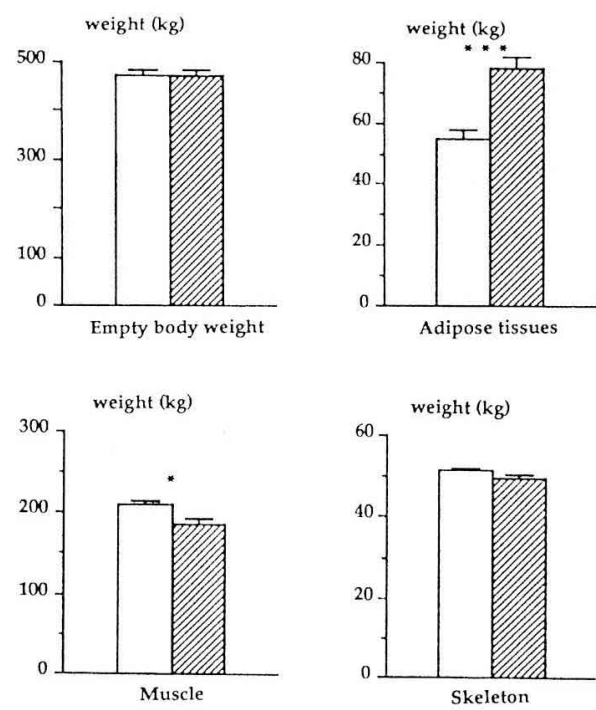

Fig 2. Weight and body composition: empty body weight; adipose deposit content; muscle weight; skeleton weight of bulls $\square$ and steers slaughter. ${ }^{\star} P<0.05,{ }^{\star *} P<0.01,{ }^{\star * \star} P<0.001$. 
Fig 3. Biochemical characteristics of muscles: total muscle protein content; isocitrate dehydrogenase (ICDH) activity (oxidative); percentage of slow myosin heavy chains (MHC1) of bulls [.] and steers measured at 9 (stage 2) and 17 months (stage 3).
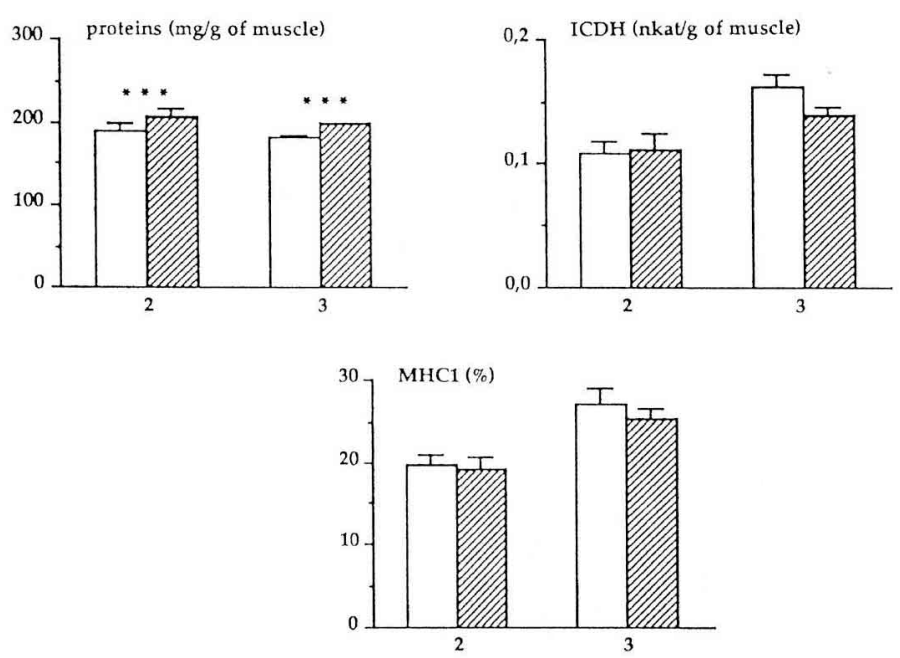

At stage 1, the only dissimilarity between animals was the higher proportion of protein in the muscles of those fed a restricted diet. Conversely, at stage 2 , restricted animals had less muscle protein than those fed ad libitum (fig 7). At this stage, significant differences were observed in the proportion of the different types of fiber. Restricted animals had fewer type I fibers and more type IIB fibers, but the same proportion of type IIA fibers as animals fed ad libitum (fig 8). While there was no difference in the surface of the latter 2 types of fibers, the surface of type I fibers was significantly smaller in restricted animals (fig 9). At stage 3 , although no significant difference was observed between the 2 groups, the animals on a restricted diet tended to have

fewer type IIB fibers and more type IIA than those fed ad libitum (fig 8).

At all 3 stages studied, the ICDH activity tended to be lower in restricted animals, but the differences were not significant (fig 7). Likewise, there was no significant difference in the percentage of $\mathrm{MHC} 1$ between the animals at any of the 3 stages (fig 7 ).

\section{DISCUSSION}

\section{Effects of castration}

The effects of castration on carcass composition observed in this study were consistent with previous findings. Castration
Fig 4. Proportions of the different fiber types: type I fibers (slow, oxidative); type IIA fibers (fast, oxidoglycolytic); type IIB fibers (fast, glycolytic) in bulls $\square$ and steers measured at 9 (stage 2) and 17 months (stage 3 ).
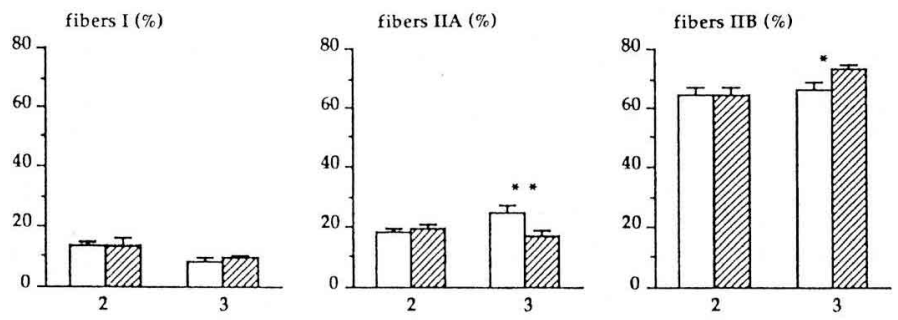

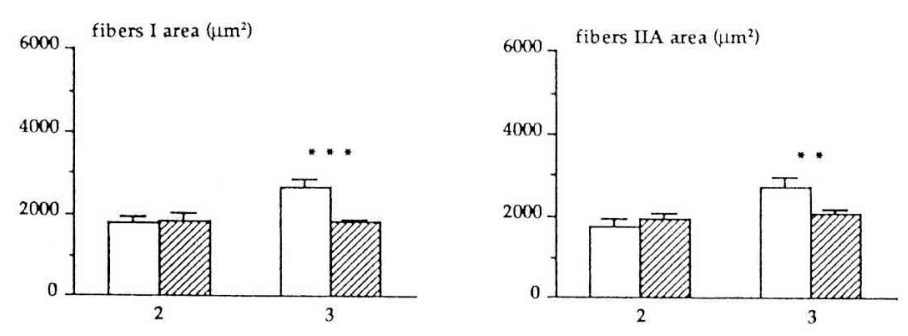

Fig 5. Surface of the different fiber types: type । fibers (slow, oxidative); type IIA fibers (fast, oxidoglycolytic); type IIB fibers (fast, glycolytic); mean surfaces in bulls and steers at 9 (stage 2) and 17 months (stage 3 ).
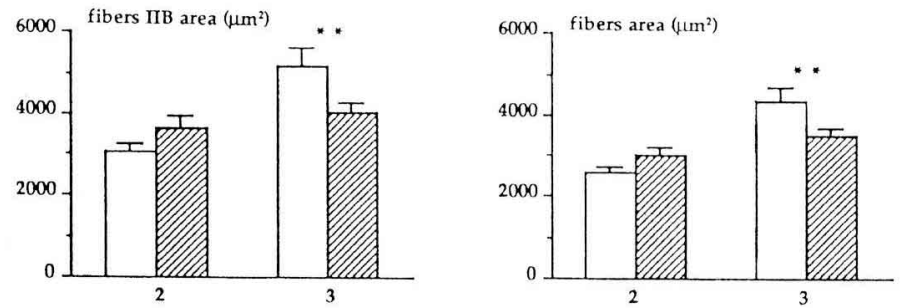

decreases muscle growth and increases adipose tissue content (Field, 1971; Raju, 1975; Seideman et al, 1982) as a result of the effect of testosterone on muscle protein anabolism. In several species, testosterone has been observed to enhance protein synthesis and hence to increase the body mass and size of certain muscles (Kochakian and Stettner, 1949; Field, 1972; Kochakian, 1975; Martinez et al, 1984; Griggs et al, 1989). In light of this evidence, it is surprising that in our experiment the protein content of ST muscles was significantly greater in the steers. It should be added, however, that the protein content measured in Masseter, Rectus abdominis and Tensor fascia lata muscles did not vary significantly between bulls and steers at the 2 stages studied (unpublished results).

The original aspect of our results was to show that changes in muscle characteristics occurred between 5 and 13 months after castration. Five months after castration, no effect on muscle characteristics was observed, whereas after 13 months, significant differences were noted between bulls and steers. The principal differences were in the size and proportion of fiber types, but all features measured varied consistently.
Between birth and 4 months of life, testosterone plasma levels in calves are at very low levels, between 0 and $1 \mathrm{ng} / \mathrm{ml}$ (Lacroix et al, 1977). However, between 4 and 6 months, high peaks may be observed
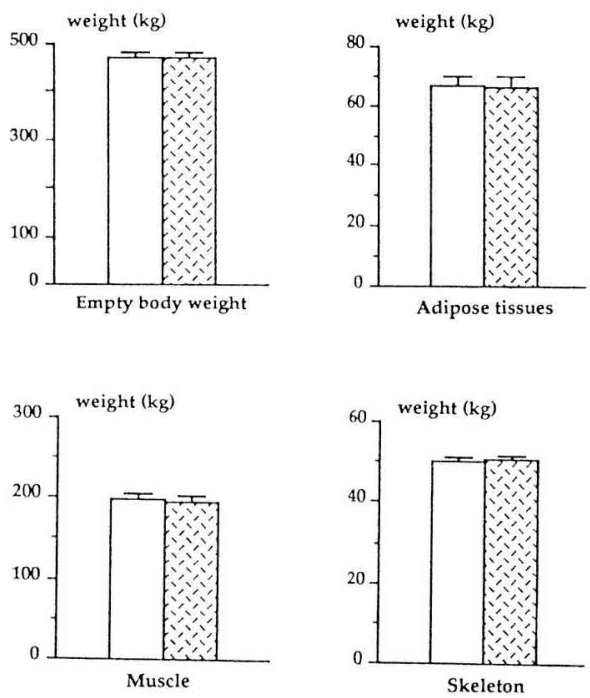

Fig 6. Weight and body composition: empty body weight; total adipose tissue content; muscle weight; skeleton weight of animals fed a restricted diet $L_{-}$or ad libitum ${ }^{2}$, measured at slaughter. 
Fig 7. Biochemical characteristics: total muscle protein content; isocitrate dehydrogenase (ICDH) activity (oxidative); percentage of slow myosin heavy chains (MHC1) of the muscles of animals fed a restricted diet $\square$ or ad libitum measured at 4 (stage 1), 9 (stage 2) and 17 months (stage 3 ).

Fig 8. Proportions of the different types of muscle fibers: type I fibers (slow, oxidative); type IIA fibers (fast, oxidoglycolytic); type IIB fibers (fast, glycolytic) of animals fed a restricted diet 政 or ad libitum $\square$, measured at 4 (stage 1), 9 (stage 2) and 17 months (stage 3).

Fig 9. Surfaces of the different types of muscle fibers: type I fibers (slow, oxidative); type IIA fibers (fast, oxidoglycolytic); type IIB fibers (fast, glycolytic); mean surfaces of animals fed a restricted diet or ad libitum $\square$, measured at 4 (stage 1), 9 (stage 2) and 17 months (stage 3 ).
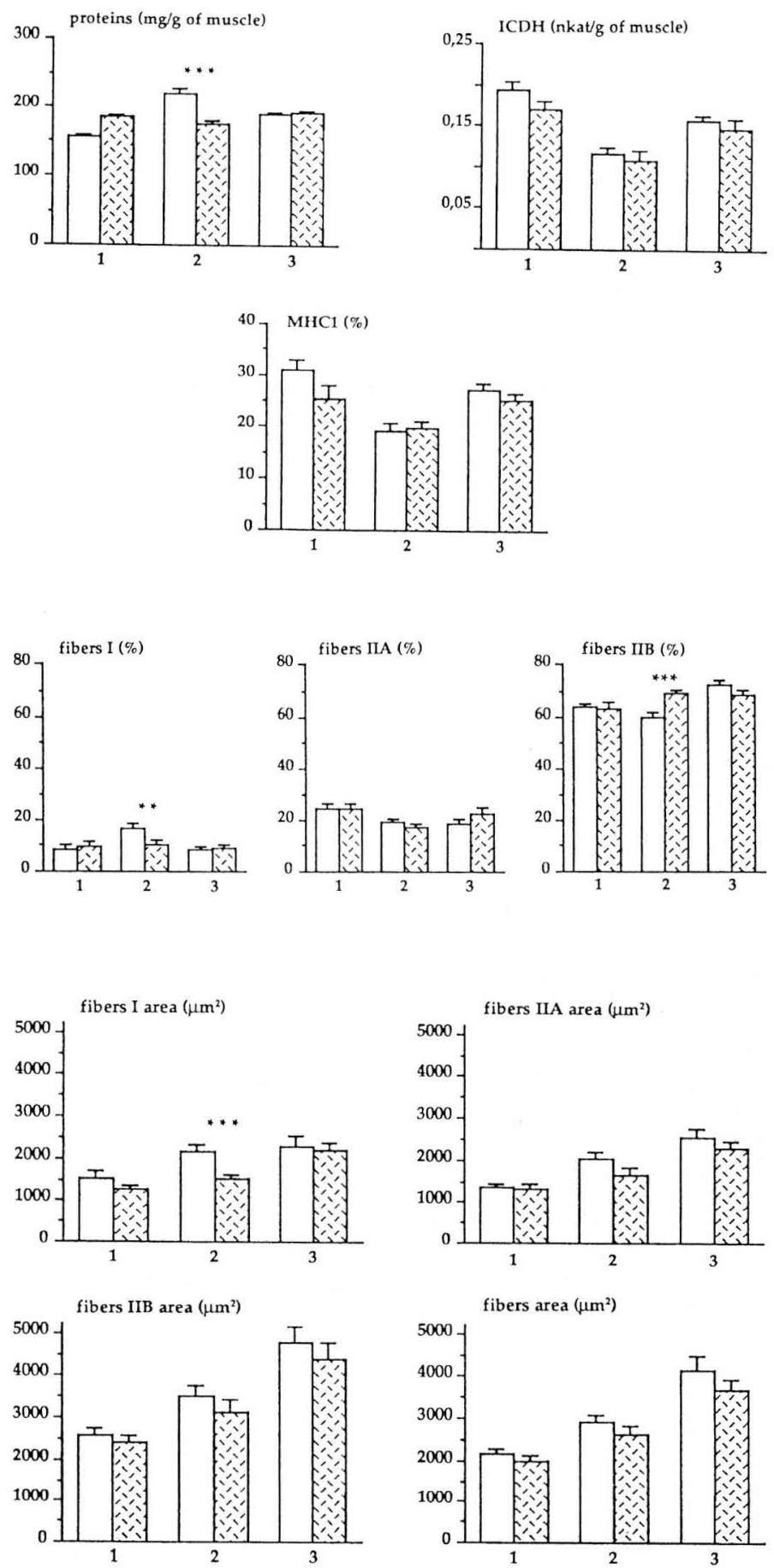
whereas between 6 and 12 months, testosterone levels return to very low levels and then increase after 12 months (Rawlings et al, 1972; Karg et al, 1975; Lacroix et al, 1977). The period from 4 to 12 months of life corresponds to the onset of puberty, which is generally completed by the age of 1 year or thereabouts (Thibier, 1975; Lacroix et al, 1977). It is likely that testosterone is present before the end of puberty but that its muscle receptor is not yet active. The hormone-receptor system may then become functional once puberty has begun. It can therefore be supposed that the differences in muscle characteristics between bulls and steers begin to occur after puberty.

The effects of castration on muscle characteristics that we observed at the age of 17 months were comparable to those reported previously in animals of various species, including cattle, but which were not castrated at the same age as in our experiment. All cell surfaces were found to be smaller in castrated animals. This difference seems to be the first effect of castration. For example, Tobin and Pécot-Dechavinne (1982) showed that 1 month after castration, the Levator ani muscle in rats were severely atrophied, not as a result of the number of fibers but of their diameter. The same effect has been observed in cattle, in different muscles and breeds (Dreyer et al, 1977; Ockerman et al, 1984; Young and Bass, 1984; Seideman and Crouse, 1986; Clancy et al, 1986). In frogs, Regnier and Herrera (1993) reported a positive correlation between fiber size and testosterone plasma levels. In contrast, Laflamme et al (1973) observed no effect of castration on fiber size, DNA and protein contents in Longissimus dorsi muscles from 10 pairs of cattle twins.

The bulls had more type IIA fibers and fewer type lIB fibers than the steers. These findings are in agreement with the results observed in different studies on cattle cas- trated at a later age (Dreyer et al, 1977; Ockerman et al, 1984; Young and Bass, 1984; Seideman and Crouse, 1986; Clancy et al, 1986). They lend weight to the hypothesis that androgens slow down the effect of age on the transformation of type IIA fibers into type IIB fibers and suggest that steroids have a modulating effect on the expression of genes encoding for myosin isoforms. Lyons et al (1986) showed that testosterone triggered the appearance of fast type 2a MHC in the Temporalis muscle of male rats. Likewise, in rat cardiac muscles, Morano et al (1990) showed that castration favored the expression of $\mathrm{MHC} 2 \mathrm{~b}$, whereas the administration of testosterone resulted in the appearance of $\mathrm{MHC} 2 \mathrm{a}$. These authors demonstrated that testosterone regulates the expression of cardiac $\mathrm{MHC}$ at a pretranslational level. Differences in the expression of $\mathrm{MHC} 2 a$ and $2 b$ have also been described by Dalla Libera et al (1980) in guinea pigs. Our results on the expression of $\mathrm{MHC} 1$ showed no significant differences between bulls and steers. However, in steers the muscles tended to contain lower percentages of $\mathrm{MHC1}$.

The oxidative mechanism of ST muscle was generally lower in the steers, but the difference was not significant. This finding is consistent with the differences observed in the proportions of the different fiber types. It is also in agreement with the well-documented observation that the muscles of bulls are redder than those of steers (Seideman and Crouse, 1986).

\section{Effects of energy restriction}

Energy restriction was observed to have an effect on muscle characteristics 5 months after it was stopped. However, at slaughter (13 months after the treatment), no significant difference was found between the 2 groups of animals. This result is at variance with different published reports 
which state that a period of undernutrition before weaning has irreversible effects on muscle characteristics (Dobbin, 1974; Bedi et al, 1982).

Results from the literature show that the effect of energy restriction on muscle characteristics differs according to whether it is implemented before or after weaning. Haltia et al (1978) and Beverly et al (1991) reported a decrease in the proportion of type I fibers accompanied by an increase in that of type IIB fibers in rats which had undergone energy restriction during the perinatal period. As rats are less developed at birth than cattle, it is difficult to compare the 2 sets of results. However, various authors have shown that energy restriction after weaning decreases the proportion of type IIB fibers and increases that of type IIA fibers in different species (Goldspink and Ward, 1979 , in rats; Moody et al, 1980; and Solomon and Lynch, 1988, in sheep; and Seideman and Crouse, 1986, in cattle). These changes are commonly explained as a consequence of the hypothyroidism that occurs during a period of undernutrition (Beverly et al, 1991). It is known that thyroid hormones regulate the expression of type IIB myosin isoform (MHC2b) (Bacou and Vigneron, 1988). The changes are accompanied by a decrease in the oxidative activity of the muscles of animals on a restricted diet (Raju, 1975; Howells and Jordan, 1978).

The size of the different fiber types is, in contrast, always decreased after a period of energy restriction, whether it be before or after weaning (Moss, 1971; Haltia et al, 1978; Goldspink and Ward, 1979; Bedi et al, 1982; Burwin et al, 1988; Lanz et al, 1992). This diminution is due to a decrease in muscle DNA and protein content (Moss, 1971; Ward and Stickland, 1993), as observed in our experiment at stage 2 (9 months, $305 \mathrm{~kg}$ ).

The differences noted in muscle characteristics at stage 2 are in agreement with the results of Haltia et al (1978) and of Bev- erly et al (1991) in rats. The fact that by the time of slaughter there were no longer any effects of energy restriction observed, either on body composition or muscle characteristics, is in agreement with the findings of Morgan (1972), who stated that undernutrition at the beginning of postnatal life had no effect on the quality of meat, as had been suggested in an early study by Winchester and Ellis (1956).

\section{CONCLUSION}

This study demonstrates the opposing effects of castration and energy restriction implemented at an early age on muscle characteristics. The effect of castration increased with age whereas restriction had only a temporary impact, which disappeared as the animal matured. It therefore yields novel results on the effects of 2 factors involved in cattle rearing - androgens and feed intake - about the contractile and metabolic characteristics of muscles. The original result of this study is that the differences in the muscle characteristics due to early castration were not observed until after puberty, which suggests that the testosterone-receptor system of the muscles was not operational until that time. The principal differences observed at slaughter were in the size and distribution of the different fiber types. In particular, steers had smaller fibers than the bulls, and their muscles contained more type IIB fibers and fewer type IIA fibers.

Undernutrition between birth and weaning had temporary effects on the distribution of type I and type IIB fibers. One of the most salient points to emerge from this study is that the energy restriction during the perinatal period has no effect on the carcass composition or on the contractile and metabolic characteristics of muscles at the standard age for slaughter of about 16 months. 


\section{ACKNOWLEDGMENTS}

The authors thank Rt Jailler and G Cuylle for animal management and slaughtering, and $\mathrm{C}$ Barboiron for chemical analysis and Rd Jailier for statistical analysis.

\section{REFERENCES}

Ansay (1974) Individualité musculaire chez le bovin : étude de l'équipement enzymatique de quelques muscles. Ann Biol Anim Biochim Biophys 14, 471-486

Bacou F, Vigneron P (1988) Propriétés des fibres mus culaires squelettiques. I. Influence de l'innervation motrice. Reprod Nutr Dev 28, 1387-1453

Bass A, Gutmann E, Hanzlikova V, Syrovy L (1971) Sexual differentiation of enzyme pattern and its conversion by testosterone in the temporal muscle of the guinea pig. Physiol Biochem 20, 423-431

Bedi KS, Birzgalis AR, Mahon M, Smart JL, Wareham $A C$ (1982) Early life undernutrition in rats. I. Quantitative histology of skeletal muscles from underfed young and refed adult animals. Br J Nutr 47, 417431

Beverly SB, Daood MJ, Laframboise WA, Watchko JF, Foley TP, Butler-Browne GS, Whalen RG, Guthrie RD, Ontell M (1991) Effects of perinatal undernutrition on elimination of immature myosin isoforms in the rat diaphragm. Lung Cell Mol Physio/ 5, 49-54

Briand $M$, Talmant A, Briand $Y$, Monin G, Durand A (1981) Metabolic types of muscle in sheep. II. Lactate dehydrogenase activity and $\mathrm{LDH}$ isozyme distribution. Eur J Appl Physio/ 46, 359-365

Burwin DG, Ferrell CL, Britton RA (1988) Effect of feed intake of lambs on visceral organ growth and metabolism. In: Energy metabolism of animals. Proc 11th Symposium INRA, 103-106

Butterfield RM (1988) New concept of sheep growth. Dept of Vet Anatomy, Univ Sidney, Epping, Australia

Clancy MJ, Janet M Lester, Roche JF (1986) The effects of anabolic agents on the fibers of the 1 dorsi mus. cle of male cattle. J Anim Sci 100-111

D'Albis A, Janmot C, Mira JC, Couteaux R (1991) Characterization of a ventricular $\mathrm{V} 1$ myosin isoform in rabbit masticatory muscles. Development and neural regulation. BAM 1, 23-24

Dalla Libera L, Sartore S, Pierobon-Bormioli S, Schiaffino $S$ (1980) Fast-white and fast-red isomyoisins in guinea pig muscles. Biochem Biophys Res Com $96,1662-1670$

Dobbing J (1974) Scientific fundations of paediatrics (JA Davis, J Dobbing, eds), Heinemann, London, Philadelphia, $565 \mathrm{p}$
Dreyer JH, Naude RT, Henning JNN, Rossow E (1977) The influence of breed, castration and age on muscle fibre type and diameter in Friesland and Africaner cattle. S Afr J Anim Sci 7, 171-180

Field RA (1971) Effect of castration on meat quality and quantity. J Anim Sci 32, 849-858

Goldspink G, Ward PS (1979) Changes in rodent muscle fiber types during post-natal growth, undernutrition and exercice. J Physiol 296, 453-469

Griggs RC, Kingston W, Jozefowics RF, Herr BE, Forbes G, Halliday D (1989) Effect of testosterone on muscle mass and muscle protein synthesis. $J$ Appl Phys iol $66,498-503$

Haltia M, Berlin O, Schucht H, Sourander P (1978) Postnatal differentiation and growth of skeletal muscle fibers in normal and undernourished rats. A histochemica and morphometric study. J Neurol Sci 36, 25-39

Howells KF, Jordan TC (1978) The effects of pre- and perinatal undernutrtion on the succinic deydrogenase content of muscle fibers from fast and slow rat muscles. Histochemistry 58, 97-102

Karg H, Gimenez T, Hartl M, Hoffman B, Schallenberger E, Schams D (1975) Testosterone, luteinizing hormone (LH) and follicle stimulating hormone (FSH) in peripheral plasma bulls: levels from birth through puberty and short-term variations. Zentralb/ Veterinarmed $[\mathrm{A}] 23,793-803$

Kelley DB, Sassoon D, Segil N, Scudder M (1989) Development and hormone regulation of androgen receptor levels in the sexually dimorphic larynx of Xenopus laevis. Dev Biol 131, 111-118

Kochakian CD (1975) Definition of androgen and protein anabolic steroids. Pharmacol Ther 1, 149-177

Kochakian CD, Stettner (1949) Renotrophic-androgenic and somatotrophic properties of further steroids. Am J Physiol 158, 51-56

Labarca C, Paigen K (1980) A simple, rapid, sensitive DNA assay procedure. Anal Biochem 102, 344-352

Lacroix A, Garnier DH, Pelletier J (1977) Temporal fluctuations of plasma $\mathrm{LH}$ and testosterone in Charolais bull calves during the first year of life. Ann Biol Anim Biochim Biophys 17, 1013-1019

Laflamme LF, Trenkle A, Topel DG (1973) Effect of castration or breed type on growth of the Longissimus muscle in male cattle. Growth 37, 249-256

Lanz JK, Donahoe M, Rogers RM, Ontell M (1992) Effects of growth hormone on diaphragmatic recovery from malnutrition. Am Physiol Soc 161, 801-805

Léger JOC, Bouvagnet P, Pau B, Roncucci R, Léger JJ (1985) Levels of ventricular myosin fragments in human sera after myocardial infraction, determined with monoclonal antibodies to myosin heavy chains Eur J Clin Invest 15, 422-429

Lowry OH, Rosebrough NJ, Farr AL, Randall RJ (1951) Protein measurement with the Folin phenol reagent J Biol Chem 193, 265 
Lyons G, Kelley A, Rubinstein W (1986) Testosteroneinduced changes in contractile protein isoforms in the sexually dimorphic temporalis muscle of the guinea pig. $J$ Biol Chem 26, 13278-13284

Martinez JA, Buttery PJ, Pearson JT (1984) Mode of action of anabolic agents. Effects of testosterone on muscle protein turn-over in the female rat. Br J Nutr 52, 515-521

Moody WG, Kemp JD, Mahyuddin M, Johnston DM, Ely $D G(1980)$ Effect of feeding systems, slaughter weight and sex on histological properties of lamb carcasses. J Anim Sci 50, 249-256

Morano I, Gerstner J, Caspar Rüegg J, Gantem U, Ganten D, P Vosberg H (1990) Regulation of myosin heavy chain expression in the hearts of hypertensive rats by testosterone. Circ Res $66,1585-1590$

Morgan JHL (1972) Effect of plane of nutrition in early life on subsequent live-weight gain, carcass and muscle characteristics and eating quality of meat in cattle. J Agric Sci (Camb) 78, 417

Moss FP (1971) The relationship between the dimensions of the fibers and the numbers of nuclei during restricted growth, regrowth and compensatory growth of skeletal muscles. Am J Anat 122, 565

Nordly DJ, Field RA, Riley ML, Kercher CJ (1987) Effects of maternal undernutrition during early pregnancy on growth, muscle cellularity, fiber type and carcass composition in lambs. J Anim Sci 64, 1419-1427

Ockerman HW, Jaworek D, Van Stavern B, Parrett N, Pierson CJ (1984) Castration and sire effects on carcass traits, meat palatability and muscle fibre characteristics in Angus cattle. J Anim Sci59, 981-990

Pearse AGE (1968) Histochemistry theoretical and applied, $2 \mathrm{~d}$ ed, vol 2 (JA Churchill, ed), London, $948 p$

Picard B, Léger JOC, Robelin J (1994) Quantitative determination of type $\mathrm{IMHC}$ in bovine muscle with monoclonal antibodies. Meat Sci 36, 333-345

Pons F, Léger JOC, Chevallay $M$, Tome FMS, Fardeau M, Léger JJ (1986) Immunocytochemical analysis of myosin heavy chains in human fetal skeletal muscle. J Neurol Sci 76, 151-163

Raju NV (1975) Effect of early malnutrition on muscle function and metabolism in rats. Life Sci 15, 949-960

Rawlings NC, Hafs HD, Swason LV (1972) Testicular and blood plasma androgens in Holstein bulls from birth through puberty. J Anim Sci 34, 435-440
Regnier M, Herrera AA (1993) Differential sensitivity to androgens within a sexually dimorphic muscle of male frogs (Xenopus laevis). J Neurobiol 24, 12151228

Robelin J, Picard B, Listrat A, Jurie C, Barboiron C, Pons $F$, Geay $Y(1993)$ Myosin expression in Semitendinosus muscle during fetal development of cattle: immunocytochemical and electrophoretic analysis. Reprod Nutr Dev 33, 25-41

SAS (1985) SAS user's guide, Version 6 Edition, SAS Institute Inc, Cary, NC, USA

Sassoon D, Gray G, Kelley DB (1987) Androgen regulation of muscle fiber type in the sexually dimorphic larynx of Xenopus laevis. J Neurosci 7, 3198-3206

Seideman SC, Crouse JD (1986) The effects of sex condition, genotype and diet on bovine muscle fiber characteristics. Meat Sci 17, 55-72

Seideman SC, Cross HR, Oltjen RR, Schanbacher BD (1982) Utilization of the intact male for red meat production: a review. J Anim Sci 55, 826-840

Solomon MB, Lynch GP (1988) Biochemical histochemical and palatability characteristics of young ram lambs as affected by diet and electrical stimulation. J Anim Sci 66, 1955

Thibier M (1975) Variations circadiennes de la LH plasmatique chez le jeune taurillon. Ann Endocrinol (Paris) 36, 205-210

Tobin C, Pécot-Dechavassine M (1982) Effect of castration on the morphology of the motor end-plates of the rat levator ani muscle. Eur J Cell Biol 26, 284288

Ward SS, Stickland NC (1993)The effect of undernutrition in the early post-natal period on skeletal muscle tissue. Br J Nutr 69, 141-150

Winchester CF, Ellis NR (1956) Delayed growth of beef cattle. USDA Tech Bull 1159

Winkelmann DA, Lowey S, Press JL (1983) Monoclonal antibodies localize changes on myosin heavy chain isozymes during avian myogenesis. Cell 34, 295306

Yambayamba E, Price MA (1991) Fiber type proportions and diameters in the Longissimus muscle of beef heifers undergoing catch-up (compensatory) growth. Can J Anim Sci 71, 1031-1035

Young OA, Bass JJ (1984) Effect of castration on bovine muscle composition. Meat Sci 11, 139-156 